\title{
GAMBARAN KONFLIK ANTAR KELOMPOK PENGGEMAR KOREAN POP DI MEDIA SOSIAL
}

\section{DESCRIPTION OF CONFLICT BETWEEN KOREAN POP FANS GROUPS IN SOCIAL MEDIA}

\author{
Narulita Sahara, Rosleny Marliani, Elisa Kurniadewi \\ UIN Sunan Gunung Djati Bandung \\ corresponding email: narulitasahara94@gmail.com
}

\begin{abstract}
Conflict between social groups is rife because of struggle for territory and limited opportunities to make the group's name big. This study aims to determine the picture of the conflict between Korean Pop fan groups on social media that have been carried away in real life. The fan groups in this study are EXO-L and ARMY. Korean pop fan groups who have been in conflict since 2016. The method in this study is qualitative. Using an exploratory case study design, a single embedded case design. Data obtained through interviews and direct observation, from the subject DR (EXO-L) and ANJ (ARMY). The results obtained indicate that the conflict between these fan groups is in accordance with the experiments conducted by Sherif et al. (1988). This occurs because of the competition which frustrates the group, which causes stereotypes, prejudice and discrimination between groups. The impact of this conflict was even experienced directly by the two subjects, because both of them are good friends in terms of studying but not in the world of K-pop.
\end{abstract}

Keywords: conflicts between groups, Korean pop fans, social media

\begin{abstract}
ABSTRAK
Konflik antara kelompok sosial marak terjadi karena perebutan wilayah dan peluang yang terbatas untuk membuat nama kelompok menjadi besar. Penelitian ini bertujuan untuk mengetahui gambaran konflik antara kelompok penggemar Korean Pop di media sosial yang sampai terbawa pada kehidupan dunia nyata (real life). Kelompok penggemar dalam penelitian ini adalah EXO-L dan ARMY. Kelompok penggemar Korean pop yang mengalami konflik sejak tahun 2016. Metode dalam penelitian ini adalah kualitatif. Menggunakan desain studi kasus eksploratif single embedded case design. Data yang didapat melalui wawancara dan observasi langsung, dari subjek DR (EXO-L) dan ANJ (ARMY). Hasil yang didapatkan menunjukkan bahwa, konflik antar kelompok penggemar ini sesuai dengan eksperimen yang dilakukan oleh Sherif, dkk (1988). Terjadi karena adanya kompetisi yang membuat frustasi kelompok sehingga menyebabkan stereotype, prasangka dan diskriminasi antar kelompok. Dampak dari konflik ini bahkan secara langsung dialami kedua subjek, karena keduanya adalah teman baik dalam hal belajar tapi tidak dalam dunia K-pop.
\end{abstract}

Kata Kunci: konflik antar kelompok, penggemar korean pop, media sosial 


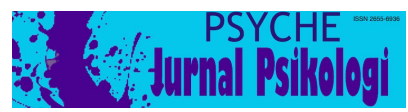

PSYCHE: JURNAL PSIKOLOGI UNIVERSITAS MUHAMMADIYAH LAMPUNG

Vol. 4 No. 1, Februari 2022

ISSN (electronic) 2655-6936

ISSN (printed) 2686-0420

\section{PENDAHULUAN}

Manusia sebagai makhluk sosial tidak dapat terlepas dari konflik, mulai dari konflik personal sampai konflik antar kelompok, dalam ranah sosial, politik, ekonomi, budaya dan agama. Gibson (1997;347, dalam Muspawi, 2014) mengatakan bahwa konflik adalah suatu pertentangan yang terjadi antara apa yang diharapkan seseorang dengan dirinya, orang lain, maupun kelompok dengan kenyataan.

Konflik terjadi karena keadaan yang tidak sesuai dengan harapan secara personal atau karena sebuah persaingan yang mengatas-namakan kelompok, menyebabkan kesalah pahaman dan prasangka. Seperti yang dikatakan oleh Sherif (1966, dalam Sarwono dan Meinarno, 2009), bias, prasangka ataupun konflik antar kelompok terjadi karena adanya kompetisi untuk memperebutkan sumber daya yang terbatas. Sumber daya ini dapat berupa benda, peluang, wilayah, orang, informasi, atau apa pun juga. Sedangkan Baron \& Byrne (2004, dalam Juditha, 2015), memandang bahwa kompetisi sejumlah kelompok sosial terhadap sejumlah peluang menyebabkan prasangka, yang mana jika kompetisi terus berlanjut, maka masing-masing anggota akan memandang kelompok lain sebagai lawan atau musuh. Pepatah mengatakan bahwa tidak akan ada asap kalau tidak ada api.

Jika konflik terjadi di dalam internal satu kelompok atau sesama anggota, maka yang terlibat dan mengetahui hanya keanggotaan di kelompok itu sendiri, sedangkan jika terjadi konflik antara kelompok, bisa sampai diketahui dan bahkan melibatkan pihak luar. Banyak hal yang menjadi penyebab kelompok itu bersitegang. Konflik karena perebutan wilayah, kekuasaan, peluang memperkuat atau membuat nama kelompok menjadi besar dan berkuasa. Jika sebuah konflik tidak cepat diselesaikan maka akan menjadi berkepanjangan yang tidak menemui akhir, kecuali salah satu kelompok menjadi lemah atau mati. Seperti eksperimen yang dilakukan Sherif, dkk. (1966, dalam Sarwono dan Meinarno, 2009), dikatakan bahwa, walaupun setelah konflik dinetralisir atau dinormalkan kembali, konflik dan rasa benci atau rasa persaingan terhadap lawan kelompok itu akan tetap ada, tidak benar-benar hilang. Kita lebih sering mendengarnya sebagai musuh bebuyutan.

Konflik yang akan menjadi fokus dalam penelitian ini adalah inter-group conflict (konflik antar kelompok), yang terjadi di media sosial. Menurut penulis, media sosial adalah 


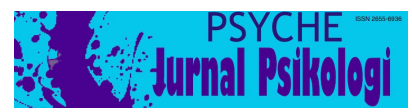

PSYCHE: JURNAL PSIKOLOGI UNIVERSITAS MUHAMMADIYAH LAMPUNG

Vol. 4 No. 1, Februari 2022

ISSN (electronic) 2655-6936

ISSN (printed) 2686-0420

sarana untuk berbagi informasi dari mulai kabar atau berita sampai pengetahuan yang berakibat pada kehidupan, dimana peran media sosial sangat penting bagi manusia karena dapat diakses kapanpun dan dimanapun. Perkembangan informasi di media sosial begitu cepat, karena banyak individu maupun kelompok yang secara bergantian aktif selama hampir 24 jam dan memberikan informasi terbaru. Besar kemungkinan perbedaan pendapat antar kelompok, kompetisi antar kelompok, dan hal lainnya yang menyebabkan konflik akan terjadi dalam dunia maya. Bohang (2018), mengatakan bahwa pengguna aktif bulanan atau biasa disebut dengan monthly active user (MAU) instagram mencapai 1 miliar per Juni 2018. Pertumbuhannya paling signifikan dibandingkan Facebook dan Snapchat, yakni mencapai 5 persen dari kuartal ke kuartal (QoQ).

Dalam media sosial, kita bisa menemukan berbagai jenis kelompok, salah satunya adalah kelompok para penggemar Korea pop (K-popers) yang juga akan menjadi fokus dalam penelitian ini. Mengapa penggemar K-popers? Karena dizaman ini atau yang disebut dengan kids/people zaman now, khususnya di Indonesia, kebanyakan perempuan dan beberapa lakilaki menyukai idol atau aktris dari Negeri Gingseng tersebut.

Nusyirwan (2018), mengatakan bahwa salah satu fenomena yaitu produk budaya yang terpenting dari kebudayaan Korea adalah musiknya yang dikenal dengan sebutan $K$ Pop. Banyak dari masyarakat Indonesia, didominasi oleh remaja dan perempuan, yang mulai menyukai musik asal Korea Selatan ini. K-pop telah mengambil alih perhatian generasi muda di Indonesia yang sebelumnya lebih menaruh minat pada lagu-lagu barat atau western. Namun, tidak semua remaja menyukai idol, karenanya ada yang disebut dengan haters yaitu sekelompok/orang pembenci yang menimbulkan peperangan secara lisan (fanwar/fandom war). Sebelum adanya aplikasi instagram, orang Korea melakukan fanwar di website dan twitter. Namun, belakangan yang dominan digunakan adalah instagram (Lastriani 2018). Fanwar adalah satu indikator dari agresif verbal (menyakiti atau melukai seseorang dengan ungkapan verbal) adalah dengan menunjukkan ketidaksukaan, berdebat, bersikap sarkastik bahkan menyebarkan gosip (Eliani, Yuniardi dan Masturnah, 2018). 
Jika satu kelompok diserang oleh anggota dan atau kelompok lainnya, maka yang menjadi anggota dan termasuk dalam kelompok tersebut akan ikut membela, maka terjadilah istilah fanwar dalam penggemar K-pop, menyebabkan konflik antar kelompok.

Matsumoto (1994), mengatakan bahwa ada yang disebut dengan konsep diri interdependen, konsep ini sesuai dengan kebanyakan orang asia, dimana budaya-budaya ini menekankan pada "kesaling-terkaitan yang mendasar pada manusia". Tugas normatif utama budaya ini adalah melakukan penyesuaian diri untuk menjadi pas dan mempertahankan interdependensi di antara individu, sehingga ada rasa saling merasakan dan memiliki. Begitu pula dengan kelompok-kelompok di media sosial. Walaupun kelompok mereka tidak resmi seperti organisasi atau perhimpunan yang lainnya, tetapi didalamnya terdapat informasi, kesukaan yang sama dan juga interaksi, maka terbentuklah sebuah kelompok. Kelompok yang saling memiliki dan serasa, dimana jika kecintaannya sudah sangat dalam terhadap kelompok atau idol yang biasa disebeut dengan fanatik, maka konflik antar kelompok benar tidak dapat dihindari. Pada dasarnya orang-orang tersebut akan membela idol dan kelompoknya apapun yang terjadi.

Kelompok yang akan diteliti adalah penggemar dari grup BTS (Bangtan Sonyeondan) yang disebut dengan ARMY, dan penggemar dari grup EXO yang disebut dengan EXO-L. BTS dan EXO adalah sekelompok laki-laki yang dapat menyanyi dan menari. BTS beranggotakan tujuh orang dan berada di bawah naungan perusahan hiburan (Big Hit). Untuk EXO beranggotakan sembilan orang dari jumlah semula 12 (dikarenakan 3 orang keluar dari grup), berada dibawah naungan SM Entertainment. Berdasarkan observasi yang dilakukan, konflik antar kelompok K-pop (EXO-L dan ARMY) terjadi di akun kelompok (fanbase) dari kedua belah pihak, juga di beberapa akun (individu dan portal $K$-pop/berita tentang K-pop) yang memancing konflik diantara keduanya. Konflik di dunia K-popers ini biasa terjadi karena adanya yang memulai pertengkaran, bisa dari ketua/admin kelompok tersebut yang memancing untuk war (perang) dalam postingannya, atau dimulai dari salah satu anggota dengan berkomentar terhadap kelompok lainnya.

Tinaliga (2018), mengemukakan bahwa karena minat dan keyakinan yang tidak selaras, penggemar tidak lagi hanya mendukung musik idol dan menyoroti keberhasilan 
mereka, tetapi juga merendahkan dan bahkan secara langsung menyerang idol atau fandom, Tinaliga mengistilahkannya sebagai toxic competitive performativity. Hampir disetiap hari ada saja kompetisi untuk memperebutkan siapa yang paling unggul sehingga terkadang konflik tidak bisa dielakkan. Walaupun tanpa ada kompetisi, jika mereka adalah musuh bebuyutan maka prasangka, persepsi atau citra satu kelompok terhadap kelompok lainnya akan tetap tidak baik.

Peneliti telah melakukan wawancara kepada seorang ARMY dan EXO-L yang juga akan menjadi subjek dalam penelitian ini. Seorang ARMY berinisial ANJ dan seorang EXO-L berinisial DR. Keduanya merupakan mahasiswa semester 5 di salah satu universitas di Bandung.

Selain dari kedua penggemar yang akan menjadi subjek peneletian tersebut, peneliti telah mewawancarai beberapa orang berbeda yang memberi sedikit informasi tentang konflik antar kelompok penggemar Korea pop ini. Peneliti mendapatkan fakta bahwa dibebera kejadian EXO-L dan ARMY ini bertengkar didunia nyata hingga saling menjambak. Hanya saja orang terkait tidak mau untuk memberikan informasi lebih lanjut. Dari hasil wawancara kedua subjek (ANJ dan DR) didapatkan hasil bahwa dari masing-masing penggemar mempunyai pandangan yang sama tentang keadaan tidak baik antara kedua kelompok penggemar tersebut.

Konflik antar kelompok K-popers dalam dunia maya tidak kalah seram dan menegangkan, dimana konfik yang terjadi antara ARMY dan EXO-L di dunia maya terbawa ke dunia nyata. Persitegangan ini uniknya bukan hanya terjadi antara ARMY dan EXO-L di Indonesia, tetapi konflik kedua penggemar ini terjadi di seluruh Negara, dan yang menjadi pusat adalah kelompok penggemar yang ada di Korea.

Penelitian yang dilakukan oleh Tinaliga (2018) tentang War For Oppa and Identity: Competitive Performativity among Korean-Pop Fandoms, berfokus pada pertengkaran penggemar K-pop Internasional di media sosial yang mendapatkan hasil bahwa, penggemar paling loyal adalah aset yang berharga bagi idol. Karena fans yang loyal akan mempertahankan citra positif idol dan mendukung kegiatan bermusik/seninya. Tapi disisi lain, fans loyal juga dapat menjadi masalah untuk idol juga kelompoknya ketika dukungan 
menjadi menyimpang. Tinaliga menyebutnya sebagai toxic competitiveness (persaignan yang beracun/berbahaya).

Penelitian lainnya oleh Ariestha (2012), tentang akar kerusuhan konflik etnik di Lampung, mendapatkan hasil bahwa akar kerusuhan karena kedua suku mempunyai masalah yang belum terselesaikan sejak dulu. Dendam, juga pelanggaran perjanjian damai oleh salah satu suku, menyebabkan konflik terus berkelanjutan.

Dari penelitian-penelitian diatas, konflik hanya berfokus pada salah satu dunia. Sedangkan, penelitian ini akan berfokus pada mengapa dan bagaimana terjadinya konflik (fanwar) antara kelompok K-popers (EXO-L dan ARMY) di media sosial bisa terbawa hingga kedalam dunia nyata, melibatkan hukum dan menyebabkan konfik antar kelompok yang tidak berkesudahan.

\section{METODE PENELITIAN}

Penelitian ini akan menggunakan teknik penelitian kualitatif studi kasus. Yin (2003, dalam Rahman, 2017), mengatakan bahwa studi kasus merupakan penelitian empirik pada suatu fenomena dalam konteks nyata, terutama apabila batasan fenomena dan konteksnya tidak terlalu jelas. Dalam psikologi, perilaku dan proses mental dan lingkungan sosial mupun fisik sering kali, satu salam lain saling memengaruhi, memiliki keterkaitan yang erat, karena itu, studi kasus cocok untuk mengurai dan mengungkap fenomena yang terjadi di Psikologi. hubungannya bersifat kompleks dan dinamis (Rahman, 2017).

Desain dalam penelitian ini adalah studi kasus eksploratif menggunakan single embedded case design. Yin (2003, dalam Rahmat 2017) mengatakan bahwa tujuan dari studi kasus eksploratif adalah untuk menggambarkan kasus yang menjadi pusat perhatian, sehingga pertanyaan apa, dimana dan kapan dimungkinkan.

Single embedded case design menurut Yin (2003, dalam Rahman 2107) yaitu, apabila yang diteliti adalah beberapa aspek dari suatu kasus seperti faktor-faktor dan proses. Dalam penelitian ini yang dimaksud berarti beberapa aspek seperti faktor-faktor dan proses terjadinya konflik antar kelompok penggemar pop Korea. Dalam penelitian ini variable penelitiannya adalah Konflik Antar Kelompok (Intergroup Conflict). 
Dalam penelitian ini subjek penelitiannya adalah satu orang berinisial ANJ dari kelompok penggemar Korean pop yang disebut ARMY, juga satu orang berinisial DR dari kelompok penggemar yang disebut dengan EXO-L. Keduanya memiliki hubungan sebagai teman, berada di universitas juga jurusan yang sama, berusia 21 tahun.

Triangulasi data dalam penelitian ini untuk mendapatkan keabsahan data, adanya perspektif dari orang lain atau orang ketiga dari subjek yang bersangkutan dengan penelitian ini yang disebut dengan significant other. Untuk significant other dari penelitian ini, dari masing-masing subjek diambil dua orang. Significant other yang pertama adalah ANJ dan DR sendiri, karena mereka adalah teman di kehidupan nyata. Significant other yang ke dua, dari subjek ANJ adalah saudara yang sangat dekat dengan subjek dan mengetahui kehidupan sehari-harinya. Untuk subjek DR yang menjadi significant other-nya adalah teman yang dekat dengan subjek dan juga mengetahui kehidupannya.

Lokasi dalam penelitian ini dilakukan di sebuah daerah Bandung yang menjadi tempat tinggal kedua subjek selama berkuliah. Instagram, facebook dan twitter sebagai wadah kedua kelompok saling berinteraksi dalam hubungan antar kelompok, tempat mulanya terjadi konflik antar kelompok dan whattsapp sebagai media untuk mengamati kedua perilaku sehari-hari subjek.

Prosedur dalam penelitian ini, peneliti mengamati terlebih dahulu apakah keadaan dilapangan sesuai dengan topik, termasuk mengamati grup yang ada di instagram yang sesuai dengan apa yang direncanakan. Setelah mendapatkan orang yang sesuai untuk dijadikan subjek penelitian, kemudian mengirimkan pesan melalui Whatsapp, meminta izin kesediaan subjek untuk menjadi subjek penelitian. Setelah subjek bersedia, kemudian melakukan wawancara untuk pengambilan data awal. Selain meminta izin terhadap orang yang akan diwawancari, juga meminta izin kepada admin (ketua) grup yang akunnya memiliki kriteria untuk konflik antar kelompok, untuk bukti dokumentasi juga observasi secara langsung kemudian dilampirkan.

Yin (2014), dalam pengumpulan data ada beberapa prinsip yang perlu diperhatikan yaitu pertama, sumber bukti yang beragam dua atau lebih tetapi menyatu dengan serangkaian temuan yang sama atau fakta. Dalam penelitian ini penulis menggunakan teknil 
wawancra, observasi secara langsung/partisipan, dokumentasi dan rekam arsip. Dalam penelitian ini bukti fisik didapat dari hasil rekaman, mencatat juga screenshoot (pengambilan gambar) dari instagram, proses konflik yang terjadi antar kedua kelompok penggemak Kpop. Yin (2014) mengatakan bahwa walaupun penggunaan dapat diobservasi langsung, sebuah perangkat dalam komputer (aplikasi) hasil cetakannya juga dapat dipakai.

Analisis data dalam penelitian ini menggunakan penjodohan pola. Yin (2014), mengatakan bahwa logika penjodohan pola berarti membandingkan pola yang diprediksikan (atau dengan beberapa prediksi alternatif) dengan pola yang berdasarkan data empirik. Karena penelitian ini menggunakan studi kasus eksploratif, maka menurut Yin (2014), polanya berhubungan dengan variable independen atau dependen dari penelitian. Pola dalam penelitian ini berhubungan dengan variabel bebas yaitu konflik antar kelompok

\section{HASIL PENELITIAN}

Hasil penelitian ini di dapat dari hasil wawancara dan observasi dari subjek primer, yaitu DR yang merupakan anggota dari kelompok penggemar EXO yang disebut EXO-L dan ANJ dari kelompok penggermar BTS yang disebut ARMY.

Tabel 1. Identitas Subjek DR dan ANJ

\begin{tabular}{lll}
\hline Identitas Diri & Subjek 1 & Subjek 2 \\
\cline { 2 - 3 } Nama & DR & ANJ \\
Usia & 19 tahun & 20 tahun \\
Jenis Kelamin & Perempuan & Perempuan \\
Pendidikan & Mahasiswi Semester 6 & Mahasiswi Semester 6 \\
Suku Bangsa & Sunda & Sunda \\
Agama & Islam & Islam \\
\hline
\end{tabular}

Hasil observasi selama penelitian didapatkan bahwa DR begitu membenci kelompok lawan seperti yang diucapkannya, sehingga tidak mau tahu tentang semua kegiatan idol maupun fans-nya setelah sering melakukan war (perang) ketika menginjak sekolah menengah. Samapai sekarang bahkan tidak ada satupun lagu milik BTS di ponselnya. Dalam keseharian yang dipantau melalui media sosial (WA, twitter dan instagram), DR tidak pernah sekalipun mengunggah perihal yang berkaitan dengan BTS maupun ARMY. DR berteman 
dengan subjek ke-2 (ANJ). Ketika pertemuan pertama untuk mengisi lembar persetujuan (peneliti, DR dan ANJ), DR bercerita tentang fanwar yang baru terjadi, tapi sebelum bercerita, ia lebih dulu mengucapkan maaf terhadap ANJ "Jadi... Sorry ya ANJ” terlihat kurang nyaman atau merasa tidak enak saat membahasnya. Saat wawancara ke dua yang dilaksanakan dikediaman peneliti, karena subjek dua berada ditempat DR melakukan wawancara, DR hampir menolak diwawancarai, tetapi ketika peneliti memastikan ANJ akan berada diluar, DR menyetujui. Saat wawancara berlangsung, ketika ANJ memasuki ruangan, otomatis pembicaraan akan berhenti dan dilanjutkan ketika ANJ keluar lagi. DR mengatakan ia tidak pernah saling membahas kelompok yang disukai ketika dalam kehidupan sehari-hari, masing-masing, tapi tetap berhubungan baik dalam hal belajar.

Berdasarkan wawancara dengan significant other dan observasi yang dilakukan peneliti, hasilnya sama. Manurut ANJ dan HA, DR merupakan orang yang kompetitif dalam hal belajar dan bukan seseorang yang akan membuat istilah yang merugikan saat konflik terjadi. Walau ANJ dan DR berteman dan terlihat baik-baik saja, dalam hal k-pop mereka tidak pernah membahas idol masing-masing. Untuk masa sekarang, DR tidak mengikuti war, hanya sebatas tahu walau terbawa emosi.

DR tidak melakukan lagi war seperti ketika menginjak sekolah menengah atas dan ketika awal menginjak bangku perkuliahan, seperti pernyataannya sendiri dan kedua significant other.

Seperti halnya DR, setelah di pantau melalui media Sosial dan kehidupan pribadi, ANJ tidak pernah sekalipun sengaja mengunggah yang berkaitan dengan EXO dan EXO-L. Subjek masih bisa mendengarkan lagu EXO sesekali tapi tidak seantuias terhadap BTS yang setiap hari hampir dibahasnya di cerita media sosial. Jika ada pencapaian BTS yang terbaru, subjek dengan bangga akan membahasnya. ANJ juga akan terbawa emosi dan mengklarifikasi dalam status di Whatsapp untuk membela idolnya. Hal ini juga didukung dengan pernyataan dari JDZ sebagai significant other.

ANJ sempat mengirimkan percakapan dengan teman EXO-L nya yang lain dan mereka hampir bertengkar karena beda paham untuk membela idol masing-masing. ANJ sempat memblokir Significant other (JDZ) yang merupakan saudaranya, karena JDZ sengaja 
menjelek-jelekkan BTS untuk mencari tahu tentang seberapa fanatiknya ANJ. ANJ juga sering dengan tiba-tiba berbicara tentang pencapaian idonya. Peneliti sempat sengaja mengatakan bahwa tidak mengingat satupun nama marga dari member BTS, kemudian ANJ membalasnya dingin. Subjek mengatakan kalau ia juga tidak mengenal anggota EXO. (Setahu subjek, peneliti menyukai EXO).

Berdasarkn hasil wawancara, kedua significant other mengatakan hal yang serupa tentang ANJ yang humble dan merupakan fangirling yang akan antusias terhadap idolnya. DR mengatakan bahwa ANJ sama seperti kebanyakan fangirl yang akan antusias saat melihat idolanya. DR juga mengatakan bahwa diawal semester ANJ masih terlihat sedikit menyukai EXO, tapi untuk saat ini lebih terfokus pada BTS.

Kedua SO mengatakan hal yang sama bahwa hubungan tidak baik antar kedua kelompok, menyebabkan keadaan tidak nyaman dan leluasa untuk melakukan fangirling bersama-sama. JDZ mengatakan ANJ bukan seorang yang suka mendiskriminasi, hanya saja untuk masalah idolnya dia akan memberi pujian berlebihan seakan yang lain tidak ada apaapanya.

\section{DISKUSI}

Berdasarkan hasil wawancara dan observasi yang telah dilakukan, maka dapat dilihat gambaran Konflik Antar Kelompok Penggemar Korean Pop di Media Sosial yang sampai menimbulkan konflik di dunia nyata. Mengacu pada eksperimen yang telah dilakukan Sherif (1988) berjudul "The Robbers Cave Experiment", dilakukan pada dua belas anak laki-laki yang dibagi manjadi dua kelompok untuk saling bersaing dan menyebabkan konflik, maka gambaran dari konflik antar kelompok penggemar Korean pop ini adalah seperti penjelasan dibawah ini.

Sherif (1966, dalam Sarwono dan Meinarno, 2009) dalam teori konflik realistiknya, mengatakan bahwa prasangka ataupun konflik antar kelompok terjadi karena adanya kompetisi untuk memperebutkan sumber daya yang terbatas. Sumber daya ini dapat berupa benda, peluang, wilayah, orang, informasi, atau apa pun juga. Berkaitan dengan konflik yang terjadi pada EXO-L dan ARMY, kompetisi yang menyebabkan konflik karena kompetisi yaitu 
acara musik, plagiarisme dan saling meng-klaim foto idola. Apabila dua orang menjadi saling interdependensi, dan interaksi atau kegiatan dan isu lebih banyak, peluang terjadi perbedaan pendapat akan terjadi dan potensi konflik semakin meningkat (Taylor, Peplau dan Sears, 2009).

Acara musik merupakan sumber utama paling besar yang menyebabkan konflik antar kelompok karena rutin diadakan. Persaingan acara musik menyebabkan kelompok yang tadinya berhubungan baik, menjadi sangat renggang sampai saat ini. Dalam acara musik, penggemar dituntut untuk bersaing, membuktikan siapa yang paling banyak memberikan suara dan berakhir mendapatkan pemenangnya, dimana ini salah satu faktor yang membuat frustasi kelompok. Seperti yang di katakana oleh Sherif (1962), ketika kelompok saling terlibat dalam kompetisi (persaingan) dan kegiatan yang sedemikian rupa membuat frustasi, sehingga perolehan atau kemenangan adalah tujuan yang diinginkan oleh satu kelompok dan menghasilkan kerugian dan kekalahan bagi kelompok yang lain. Sehingga ketika EXO mendapatkan kekalahan yang pertama sekitar tahun 2016, kedua kelompok menjadi berkonflik sampai saat ini. DR sebagai EXO-L dan ANJ sebagai ARMY mengatakan bahwa kebanyakan EXO-L tidak menerima kekalahan sehingga terjadilah pertengkaran di media sosial. Menurut kedua subjek, salah satu faktor yang lain adalah, mungkin saja acara musik sengaja melakukan kerusuhan untuk menaikkan rating, memanfaatkannya untuk ramai diperbincangkan. Ardianto (2011, dalam Watie, 2011) mengatakan bahwa jejaring sosial atau yang disebut dengan media sosial bukanlah merupakan media massa karena media sosial memiliki kekuatan sosial untuk memengaruhi opini publik yang ada di masyarakat.

Konflik yang tadinya hanya sebatas persaingan pengambilan suara terbanyak, meluas menjadi konflik yang besar, karena tidak pernah ada penyelesaian. Acara musik tidak berhenti memberikan bumbu penyebab konflik, sampai dimana hukum terlibat. Salah satu acara musik memberikan spekulasi yang menyebabkan penggemar menerka-nerka, kiranya siapa yang berbuat curang dalam pemberian suara (illegal voting). DR yang merupakan EXOL mengatakan bahwa saat itu ada pihak ARMY yang mengatakan tanpa data di sebuah media sosial (twitter), bahwa yang melakukan illegal voting adalah fanbase terbesar EXO-L Korea yang bernama (EXOLAB). Kelompok tersebut yang tidak terima akhirnya berhenti 
sementara waktu (vakum) dari media sosial dan fokus menyelidiki, kemudian mengambil jalur hukum untuk menyelesaikannya. Pada akhirnya terbukti EXOLAB tidak bersalah dan pihak acara musik memberi klarifikasi yang terlambat saat konflik sudah membesar, mengatakan memang bukan EXO-L yang melakukan kecurangan. Walau salah satu pihak ARMY kemudian meminta maaf, tapi konflik tidak selesai sampai disitu, malah menjadi panjang sampai saat ini. Sedangkan ANJ sebagai ARMY tidak mengetahui tentang kasus ini.

Konflik yang terjadi semakin meluas, kedua kelompok mulai saling mencari kesalahan dan saling membuat istilah yang tidak menguntungkan. Seperti EXO-L menyebut ARMY dengan sebutan kremi, batues, bites dan playing victim. Sedangkan ARMY menyebut EXO-L sebagai grup gagal (flop), egg/eggso (plesetan dari kata EXO/EXO-L) dan toxic (beracun). Kedua kelompok akan saling melemparkan kata ejekan saat perang dimedia sosial, menjadikan istilah tersebut ciri khas dari kelompok dalam untuk kelompok luar.

"....perolehan atau kemenangan adalah tujuan yang diinginkan oleh satu kelompok dan menghasilkan kerugian dan kekalahan bagi kelompok yang lain, stereotip tidak menguntungkan digunakan dalam relasi untuk kelompok luar dan anggotanya. (Sherif, 1962)."

Keadaan masa lalu yang tadinya tidak menjadi masalahpun menjadi objek untuk fanwar. Dimana kedua kelompok akan saling menuduh tentang memplagiat konsep music video, termasuk warna fandom, selogan antara idol dan fans, juga pakaian yang dikenakan.

Seperti yang dikatakan oleh Sherif (1962), seiringnya timbal balik prasangka antar kelompok luar, sikap memuliakan diri terhadap kelompok sendiri diperkuat. Sedangkan yang ditampilkan terhadap kelompok luar adalah mencela dan dirasa pergerakan anggota kelompok luar adalah mencurigakan. Sama halnya untuk kedua kelompok ini (EXO-L dan ARMY). Saat kelompok luar mencela dan mencurigai, maka kelompok dalam memperkuat dengan cara memuliakan dan membenarkan diri. Ini terjadi dibeberapa kasus, pertama saat EXO-L mengatakan bahwa BTS memplagiat seragam sekolah untuk musik video, pihak ARMY membela dengan mengatakan bahwa tidak mungkin konsep music video bertema sekolah tidak memakai seragam. Sama halnya saat ARMY mengatakan konsep rumput di musik video EXO memplagiat musik video milik BTS, pihak EXO-L membela diri dengan mengatakan bahwa itu sudah lama digunakan bahkan oleh grup senior. Kedua, saling 
mencurigai. EXO-L mengatakan bahwa ARMY sering mengklaim foto member EXO menjadi member BTS, mengatakan ARMY tidak mengenal idolnya sendiri. Sedangkan pihak ARMY mengatakan itu berawal, karena sebelumnya ada pihak EXO-L yang masuk kedalam aplikasi percakapan milik BTS dan ARMY, kemudian mengunggah foto member EXO dan berakhir dikeluarkan. Ketiga, saling mencela. Saat EXO-L mengatakan bahwa konsep menari diatas air yang dilakukan salah satu member BTS diacara musik adalah plagiat karena member EXO lebih dulu melakukannya, maka ARMY mengatakan bahwa itu adalah konsep dari yang mengadakan acara musik. Kemudian ketika pihak ARMY mengatakan bahwa member BTS lebih baik menari diatas air dari pada member EXO, maka EXO-L membalas dengan beberapa pretasi yang telah didapatkan.

Setelah dilakukan wawancara, kedua subjek mengatakan hal yang bertentangan tentang siapa yang lebih dulu seringkali menimbulkan konflik. Hasilnya, kedua subjek saling menuduh, DR sebagai EXO-L mengatakan pihak ARMY-lah yang selalu memulai pertengkaran terlebih dahulu, sedangkan menurut ANJ sebagai ARMY, mengatakan pihak EXO-L lah yang selalu memulai pertengkaran. Selain saling menuduh siapa yang memulai pertengkaran terlebih dahulu, kedua subjek mengatakan bahwa fans yang belum dewasalah (siswa SD/SMP) penyebab konflik terjadi. Sedangkan menurut observasi peneliti, bukan hanya fans yang belum dewasa saja yang terlibat jika kemudian melibatkan hukum. Contoh kasus terbaru yang dikatakan oleh ANJ, ada dari pihak EXO-L yang meng-edit salah satu foto member BTS yang disamakan dengan gorilla, berakhir dilaporkan pada polisi dan diselidiki. Walau kemudian pihak EXO-L meminta maaf, tapi ARMY mengatakan bahwa menyamakan manusia dengan hewan itu sangat berlebihan. Sedangkan DR tidak mengetahui tentang kasus ini.

Sikap antar kelompok seperti prasangka dan perilaku kelompok seperti praktik diskriminatif merujuk pada perilaku dan sikap yang dimanifestasikan oleh anggota kelompok maupun secara perorangan maupun kolektif. Ada enam karakteritis kritis tiga yang menguntungkan diantaranya adalah tangguh, ramah dan berani. Sedangkan tiga istilah yang negarif atau tidak menguntungkan adalah smart aleks atau alek yang pintar (sarkastik, kasar, atau humoris dengan cara yang ofensif, sombng atau menjengkelkan), licik, busuk atau 
bau busuk. Keanggotaan individu dalam sebuah kelompok berkaitan dengan karakteristik sikap antar kelompok, perilaku dalam kelompok (ingroup) dan sikap terhadap (outgroup) kelompok lain (Sherif, dkk, 1988).

Seperti yang dikatakan diatas, maka ketika konflik terjadi, kedua subjek mengatakan bahwa saat menjadi pihak kelompok dalam, anggota atau fans yang membela idol dan kelompoknya sendiri secara mati-matian akan mendapatkan ucapan terima kasih dan apresiasi (hebat, keren). Menurut ANJ, khusus untuk ARMY diberi julukan Hero Bangtan. Sedangkan bagi kelompok luar, itu perbuatan yang sombong dan menjengkelkan. Selain ketika konflik terjadi, masing-masing kelompok akan berlomba untuk melakukan kegiatan sosial untuk mengharumkan nama idol, kerena prinsip mereka adalah "like fans like idol", yang berarti penggemar adalah cerminan dari idolanya.

".......if the enemy kills fifty of us he is labeled "fanatic" and "cruel", but the in-group member is cited as "brave" or "heroic" for killing the enemy (Sherif, 1962).

Kedua subjek mengatakan bahwa tidak tahu kapan konflik ini akan berakhir, yang pasti tidak dalam waktu dekat. DR mengatakan sempat diadakan perundingan resmi untuk damai, tapi tidak bertahan lama dan konflik kembali terjadi. Seperti yang dikatakan Sherif, dkk. (1966, dalam Sarwono dan Meinarno, 2009), walaupun setelah konflik dinetralisir atau dinormalkan kembali, konflik dan rasa benci atau rasa persaingan terhadap lawan kelompok itu akan tetap ada, tidak benar-benar hilang. Jika sebuah konflik tidak cepat diselesaikan maka akan menjadi berkepanjangan yang tidak menemui akhir, kecuali salah satu kelompok menjadi lemah atau mati. Di tahun 2021 ini, terlihat kedua kelompok masih sama besar dan berpengaruh, sehingga konflik masih terus berlanjut. Dampaknya bahkan secara langsung dialami kedua subjek, dimana keduanya adalah teman baik dalam hal belajar tapi tidak dalam dunia K-pop. Karena hubungan kedua kelompok yang tidak baik, secara tidak kasat mata terdapat sebuah batasan, sehingga keduanya lebih nyaman untuk tidak saling membahasnya (membicarakan idola masing-masing) daripada hubungan yang sudah terjalin menjadi buruk.

\section{KESIMPULAN DAN SARAN}


Sebagaimana yang telah dipaparkan, gambaran konflik antar kelompok Korean pop pada EXO-L dan ARMY, dapat dilihat dari beberapa aspek. Seperti yang dikatakan Sherif (1988), yang pertama adanya kompetisi yang membuat frustasi. Dalam hal ini acara musik menjadi momok dalam konflik antar kelompok. Kedua, adanya stereotype. Dalam stereotype, adanya pertengkaran dan mulai membuat ungkapan khusus. EXO-L terhadap ARMY (kremi, batu es, bites, playing victim) dan ARMY terhadap EXO-L (flop, eggs/eggsoel, toxic). Ketiga, adanya prasangka terhadap kelompok luar (mencurigai dan mencela) dan prasangka terhadap kelompok dalam (membenarkan dan memuliakan diri). Keempat, adanya diskriminatif. Diskriminatif dibagi menjadi dua, untuk kelompok dalam adalah istilah yang menguntungkan seperti berani, tangguh dan ramah. Sedangkan untuk kelompok luar adalah istilah yang tidak menguntungkan, seperti licik, smart aleks (sarkastik, menjengkelkan, sombong) dan bau busuk.

Mengacu pada penelitian yang telah dilakukan oleh peneliti dalam keterbatasanketerbatasan yang dimiliki, peneliti mengajukan saran-saran untuk dijadikan bahan pertimbangan guna mengembangkan penelitan dan ilmu pengetahuan, diajukan kepada:

Kelompok penggemar Korean pop. Subjek DR mengatakan bahwa "Jangan ada fanwar lagi. Semua idol yang kita sukai atau yang kalian sukai itu emang punya kelebihan masing-masing dan itu engga bisa dibandingin sama sekali. Mungkin, banyak kekurangan, tapi disitu juga lebih banyak kelebihan idol masing-masing dan menurut aku gak etis kalo misalkan harus di bandingin satu sama lain". Subjek ANJ mengatakan bahwa "Tidak ada idol yang suci, semua memiliki kekurangan dan kelebihannya masing-masing. Jangan pedulikan hinaan dan fokus meraih prestasi".

Penelitian selanjutnya. Untuk penelitian selanjutnya sebaiknya menggunakan referensi buku yang lain selain menggunakan teori konflik realistik dari Sherif. Selanjutnya lebih banyak lagi menggali informasi tentang konflik antara kelompok lebih jauh sehingga mendapatkan hasil yang lebih mendalam.

\section{DAFTAR PUSTAKA}

Ariestha, Bertha. (2012). Akar Konflik Kerusuhan Antar Etnik di Lampung Selatan. Journal of Social and Industrial Psychology, 1(2) 
Bohang, Fatimah Kartini. (2018, Februari 18). Pengguna Aktif Instagram Tembus 1 Miliar. Diambil dari websites Kompas.com: https://tekno.kompas.com/read/2018/06/21/10280037/juni-2018-penggunaaktif-instagram-tembus-1-miliar

Eliani, J., Yuniardi, M.S., \& Masturah, A.N. (2018). Fanatisme dan Perilaku Agresif Verbal di Media sosial Pada Penggemar Idola K-Pop. Jurnal Penelitian Psikologi, 3(1), DOI: http://dx.doi.org/10.21580/pipp.v3i1.2442

Juditha, Christiany. (2015). Stereotip dan Prasangka dalam Konflik Etnis Tionghoa dan Bugis Makassar. Jurnal Ilmu Komunikasi, 12 (1), 87-104

Lastriani. (2018). Fanwar: Perang antar Fans Idola K-Pop di Media Sosial. Jurnal Emik, 1 Matsumoto, David. (1994). Pengantar Psikologi Lintas Budaya. Terjemahan oleh Anindito Aditomo. Yogyakarta: Pustaka Pelajar

Mulawarman \& Nurfitri, A.D. (2017). Perilaku Pengguna Media Sosial Beserta Implikasinya. Ditinjau dari Perspektif Psikologi Sosial Terapan. Buletin Psikologi, 25(1), DOI: 10.22146/buletinpsikologi.22759

Nusyirwan, Halimah. (2018, Februari 21). Menjamurnya K-pop di Tengah Generasi Muda Indonesia. Diambil dari Kinibisa News: https://kinibisa.com/news/read/menjamurnya-k-pop-di-tengah-generasi-mudaindonesia

Rahman, A.A. (2017). Metode Penelitian Psikologi: Langkah Cerdas Menyelesaikan Skripsi. Bandung: PT Remaja Rosdakarya Offset

Sarwono, Sarlito W \& Meinarno, Eko A. (2009). Psikologi Sosial. Jakarta: Penerbit Salemba Humanika.

Sherif, M., White, B.J., Hood, W.R., \& Sherif, C.W. (1988). The Robbers Cave Experiment: Intergroup Conflict and Cooperation. United State of America First Wesleyan Edition.

Taylor, S.E., Peplau, L.A., \& Sears, D.O. (2009). Psikologi Sosial: Edisi ke Dua Belas. Terjemahan oleh Tri Wibowo. Jakarta: Kencana Prenada Media Group

Tinaliga, B. (2018). At War For Oppa and Identity: Competitive Performativity among Korean-Pop Fandoms. Master Projects and Capstones, 768

Watie, E.D.S. (2011). Komunikasi dan Media Sosial: Communications and Social Media. The Messenger Ilmu Komunikasi Universitas Semarang, 3(1)

Wiley, J. \& Inc, Sons. (1962). Intergroup Relations and Leadership: Approach and Research in Industrial, Ethnic, Cultural, and Political Areas. In Sherif, M (Ed), Intergroup Relations and Leadership: Introductory Statement (h. 3-21).

Yin, R.K (2014). Studi Kasus: Desain \& Metode. Terjemah oleh Mudzakir, D. Jakarta: Rajawali Pers. 